\title{
The Legality of Nuclear Free Zones
}

\author{
Lori A. Martin $\dagger$
}

Numerous municipalities and local governments throughout the United States have enacted various sorts of Nuclear Free Zones ("NFZs"). In light of the extensive federal power over foreign affairs, the legality, both constitutional and statutory, of these local regulations is questionable. Only a few Supreme Court cases have examined how the affirmative grant of power over foreign affairs to the national government may restrict the authority of state and local governments to enact regulations touching upon defense policy. Moreover, no clear test emerges from these cases.

This comment sets out an analytic framework for evaluating the legality of Nuclear Free Zone legislation. The comment will argue that statutory preemption is the primary obstacle to NFZ legislation. Where Congressional and executive intent to preempt is ambiguous, however, the constitutionally defined scope of the foreign affairs powers may be an important guide to the preemptive effect of a statute or executive policy. Moreover, the constitutional allocation of powers itself generates some significant restrictions upon the power of states to legislate in ways affecting foreign affairs. The analytic framework that emerges from these arguments draws upon some aspects of modern dormant commerce clause jurisprudence, although the justification for this "dormant foreign affairs" analysis differs significantly from that applicable to the commerce clause. The comment will conclude by applying the framework to four hypothetical NFZs: (1) a statute banning from the locality both navy ships carrying nuclear weapons and the deployment of land-based missiles; (2) a statute banning the manufacture of nuclear weapons or materials used in nuclear weapons within the locality; (3) a statute barring nuclear weapons contractors from contracting with the municipality; and (4) a statute subjecting all producers of toxic materials within the municipality, including defense contractors, to restrictive local health and safety regulations.

† B.A. 1985, Wellesley College; J.D. Candidate 1988, The University of Chicago. 


\section{What aRe Nuclear Free Zones?}

By October 1987, there were 139 NFZs in the United States. ${ }^{1}$ They have been created by ordinances, resolutions, by-laws, referenda, and advisory petition initiatives, and have been passed by city councils, village boards, citizens' corporations, community boards, Indian tribal councils, borough councils and counties. ${ }^{2}$ Generally, supporters of NFZs seek to eliminate the manufacture and deployment of nuclear weapons within a locality. ${ }^{3}$ But some NFZs also address other aspects of nuclear technology, including nuclear power plants. Although sometimes merely advisory, most NFZ measures are binding ordinances and charter amendments.

While the provisions of NFZs vary from community to community, many are patterned after the Model Nuclear Weapons Free Zone Ordinance ${ }^{4}$ and consequently share several common provisions: (1) the phaseout of development, production, deployment, launching, maintenance, or storage of nuclear weapons or components of nuclear weapons; (2) the prohibition of commencement of nuclear weapons work; and (3) the conversion of resources and physical plants to peaceful and productive uses.

Some NFZ legislation goes much further than the model ordinance. There are NFZ measures which seek to ban the use of city property in the construction of naval home ports for vessels that carry nuclear missiles. ${ }^{5}$ Some NFZs ask foreign nations suspected of having nuclear technology to remove the NFZ community from the foreign nations' "target" lists. ${ }^{6}$ The language of the NFZ statutes is carefully worded so as to exclude direct regulation of the activities of the federal government. ${ }^{7}$

Other NFZ provisions address the manufacture of nuclear weapons across the country. For example, some NFZs prohibit the transportation of nuclear weapons through the local jurisdiction. ${ }^{8}$ At least seven NFZs bar the local government from investing in, or

- Nuclear Free Zones in the United States, New Abolitionist (Newsletter of Nuclear Free America) 10 (Oct. 1987).

2 Id.

${ }^{3}$ Gordon C. Bennett, The New Abolitionists: The Story of Nuclear Free Zones 7 (1987)("[T]he movement is primarily directed against nuclear weapons . . . .").

4 See Mark C. Cogan, Planning for a Nuclear Weapons Free Environment: Model Legislation and Legal Commentary 7-14 (1985).

- For example, the New York City referendum at issue in Fossella v. Dinkins, discussed below in Section II.A, sought to ban the use of New York City harbors as a Navy home port. For citations to the multiple reported decisions in the case, see note 20.

- Bennett, The New Abolitionists at 7 (cited in note 3).

7 Cogan, Planning for a Nuclear Weapons Free Environment at 11 (cited in note 4).

8 Id. at 13. 
contracting with nuclear weapons contractors, ${ }^{9}$ broadly defined to include manufacturers of electrical and computer parts adapted for nuclear weapons. ${ }^{10}$ The investment ban is intended to exert influence upon nuclear weapons contractors to abandon their work on nuclear weapons in favor of work that contributes to the public welfare. ${ }^{11}$

Local governments seek to address two concerns when they enact NFZs. First, they fear that the nuclear arms race threatens the health, safety and economic well-being of local citizens due to the local presence of nuclear weapons. Local governments are particularly concerned that the presence of nuclear weapons or the nuclear weapons industry in their immediate locale could make their community the target of hostile military action or terrorism. ${ }^{12}$ But the ordinances are also motivated by concern that nuclear weapons are inherently unstable, subject to inadvertent explosion..$^{13}$

Second, the NFZ movement is broadly targeted at the federal nuclear weapons defense strategy. The grass roots movement seeks to reduce the world's nuclear weapons arsenals through local action. ${ }^{14}$ The passage of a NFZ is intended to send a symbolic message to Congress that a local community does not want to be defended by nuclear weapons. ${ }^{15}$ The movement seeks to force the national government "to think more carefully about where their weapons can be designed, manufactured, stored, or transported, and how they can dispose of waste without running afoul of local restrictions." 16

During the next year, the NFZ campaign will expand local ef-

- These seven are in Amherst, Massachusetts; Berkeley, California; Hayward, California; Eugene, Oregon; Jersey City, New Jersey; Marin County, California; and Takoma Park, Maryland. Nuclear Free America, Nuclear Free Zone Legislation Data (Dec. 30, 1987) (on file with The University of Chicago Law Review).

${ }^{10}$ Nuclear Free America, Nuclear Free Investment Sample Legislation \& I(e) (Jan. 1985) (on file with The University of Chicago Law Review).

"See, for example, Marin County Nuclear Free Zone Ordinance, No. 2924, preamble, cl. 8 (1986) (on file with The University of Chicago Law Review).

${ }_{12}$ Cogan, Planning for a Nuclear Weapons Free Environment at 8 (cited in note 4).

${ }^{13}$ Lawsuit Seeks to Stop Homeport Construction, New Abolitionist 4 (Oct. 1987).

14 Albert Donnay, the Director of Nuclear Free America, has stated that "nobody is going to stop the arms race for us, certainly not Congress or the President. We all have to decide for ourselves what to do about it . . . . The people who support Nuclear Free Zones are changing the nation's policies. They're just doing it at the local level instead of asking (and waiting) for politicians in Washington to do it for them." Bennett, The New Abolitionists at 8,24 (cited in note 3 )(emphasis in original).

15 Id. at 170.

${ }^{16}$ Id. at 51. 
forts to curb the nuclear arms race. On November 3, 1988, five anti-nuclear petitions will be considered in Maine, California, and New Jersey. The two California measures ban contracting with nuclear weapons manufacturers and contractors. The Maine referendum concerns the continued operation of nuclear power plants within the state. And the two New Jersey measures seek to prohibit the "harmful applications of nuclear technology."17 In addition, one woman is seeking a federal injunction halting the construction of navy home ports in Galveston and Corpus Christi, Texas. $^{18}$

\section{Applicable Doctrine}

This section examines the case law and doctrinal issues surrounding the legality of Nuclear Free Zones. Subsection A examines two recent lower court cases on point. Subsection B considers at a more general level the federalism issues arising under the war and foreign affairs clauses ${ }^{19}$ of the Constitution. Subsection $\mathrm{C}$ suggests that the lack of a cohesive framework for analysis of the scope of state and federal foreign affairs powers has left lower federal and state courts without guidance for analyzing local regulations which affect national defense programs.

\section{A. Local Attempts to Negate the Harmful Effects of U.S. Defense} Programs on Specific Communities.

\section{Fossella v. Dinkins ${ }^{20}$ and Arthur D. Little, Inc. v. Commis-}

17 On the Ballot November 3rd, New Abolitionist 3 (Oct. 1987).

${ }^{18}$ Lawsuit Seeks to Stop Homeport Construction, New Abolitionist 4 (Oct. 1987).

19 Congress' enumerated powers include art. I, \& 8, cl. I ("provide for the common defence"); art. I, § 8, cl. 4 ("establish an uniform rule of naturalization"); art. I, § 8, cl. 11 ("declare war"); art. I, § 8, cl. 12 ("raise and support armiss"); art. I, § 8, cl. 13 ("provide and maintain a navy"); and art. I, § 8, cl. 14 ("make rules for the government and regulation of the land and navy forces").

The President's enumerated powers include art. II, $\S 2$, cl. 1 ("commander in chief of the army and navy of the United States") and art. II, $\S 2$, cl. 2 ("power, by and with the advice and consent of the senate, to make treaties, provided two-thirds of the senators present concur"). In addition to any enumerated powers, the federal government has such powers over foreign affairs that are inherent in nationhood and sovereignty. See text accompanying note 130 .

20495 N.Y.S.2d 352, 66 N.Y.2d 162 (1985), aff'g, 494 N.Y.S.2d 878, 110 A.D.2d 227 (2nd Dept.), aff'g, 494 N.Y.S.2d 1012, 130 Misc.2d 52 (Sup.Ct.Richmond County). The Appellate Division and the Supreme Court reached the constitutional issue. New York's highest court, the Court of Appeals, instead struck the referendum from the ballot on the basis of state municipal corporation law. Two other opinions in the case adjudicated the suit's ripeness. See 493 N.Y.S.2d 859, 114 A.D.2d 340 (2nd Dept. 1985), aff'g and remitting, 493 N.Y.S.2d 947, 128 Misc.2d 822 (Sup.Ct.Richmond County). 
sioner of Health and Hospitals of Cambridge ${ }^{21}$ discuss directly the constitutional restrictions on local regulations that may interfere with federal authority over military and foreign affairs.

In Fossella, the New York Supreme Court, affirmed on similar reasoning by the Appellate Division, held unconstitutional a petition filed with the New York City clerk for a referendum to amend the New York City charter. The challenged referendum would have prohibited local municipal authorities "from consenting to the use of city owned property for the development of any military facility" designed to carry or maintain nuclear weapons. ${ }^{22}$ The grass roots movement that initiated the referendum specifically opposed the city's plans to cooperate with the United States Navy in the construction of a Staten Island home port for the battleship U.S.S. Iowa and its support vessels. ${ }^{23}$

The New York Appellate Division and Supreme Court both held that the proposed referendum would interfere with the federal government's power "to provide for a common defense and to regulate the army and navy."24 The courts' analysis rests on two controversial premises about the allocation of power between the national and local governments.

The first premise is that some of the powers assigned to the national government, especially national defense powers, are plenary and exclusive such that the states cannot legislate with respect to matters within the scope of those powers. ${ }^{25}$ Because national defense is a collective concern of Americans as a nation, no single locality has an interest in military defense that differs from the interest of any other locality:

We are one people. The United States vests in the Federal Government the obligation to provide defense to the entire nation and all of its people without regard to their location .... A necessary correlative to the duty imposed upon the Federal Government is the right it enjoys to make and effectuate decisions respecting the deployment of defense systems, within the United States, unfettered by local regulation designed to impede its efforts. ${ }^{26}$

Second, the Appellate Division held that there are no legiti-

21395 Mass. 535, 481 N.E.2d 441 (1985).

22494 N.Y.S.2d at 879.

23493 N.Y.S.2d at 949 .

24494 N.Y.S.2d at 879.

25 Id. at 880.

${ }^{28} 494$ N.Y.S.2d at 1016. 
mate local concerns that justify interference with the federal regulation of national defense. The court construed the "broad and sweeping" power of the federal government to raise and maintain defense forces as not subject to local qualification or limitation. ${ }^{27}$ Accordingly, even a good faith local concern that the deployment of conventional or nuclear weapons could pose a danger to the local population was an insufficient justification for local interference with federal defense programs. ${ }^{28}$ While admitting that the effect on federal defense strategies of a single local government regulation could be minimal, the court reasoned that "if every local government were given the power to restrict the establishment and operation of Federal military installations or weaponry located within its geographical jurisdiction, the power of the Federal government to raise and maintain an army and navy would . . . be destroyed."2o

Both of the courts concluded that in matters of national defense, the test for assessing the validity of local laws is whether those laws impair "the efficiency of [defense-related] agencies of the Federal government." 30 The test is sufficiently broad to invalidate local regulations that might require the national government "to expend additional time, money and resources in legal or administrative action" 31 to overcome the effects of the ordinance. If local health concerns fail to legitimize interference with national defense, local rejections of national defense policy are precluded $a$ fortiori. A local ordinance is thus precluded if the purpose of the law is to obstruct the federal defense program "because of local disagreement with national defense policies." 32

Arthur D. Little, Inc. rejected the second premise of Fossella, which assumed that local measures must not deleteriously affect federal defense programs. The Supreme Judicial Court of Massachussetts upheld a municipal regulation that prohibited the testing, storage, transportation, and disposal within Cambridge city limits of five highly toxic chemical warfare agents. ${ }^{33}$ The Cambridge Commissioner of Health and Hospitals issued the contested

${ }^{27} 494$ N.Y.S.2d at 880, quoting United States v. O'Brien, 391 U.S. 367, 377 (1968).

${ }^{28} 494$ N.Y.S.2d at 880 .

28 Id. added).

${ }^{30}$ Id. at 881, quoting Davis v. Elmira Savings Bank, 161 U.S. 275 (1896)(emphasis

31494 N.Y.S.2d at 1016.

${ }^{32}$ Id. at 1017.

${ }^{33} 481$ N.E.2d at 443 . The Cambridge regulation restricted the use of five specific chemical materials: (1) Soman-GD (nerve agent), (2) Sarin-GB (nerve agent), (3) VX (nerve agent), (4) Mustard-HD (blister agent), and (5) Lewisite (blister agent). Id, at 444 n.2. 
regulation shortly after Arthur D. Little, Inc. commenced the testing of small quantities of chemical warfare agents at the Levins Laboratory in Cambridge, Massachusetts, pursuant to a contract with the Department of Defense. The Commissioner required that testing cease until a scientific advisory committee could conduct an "independent hazard assessment" of the chemicals. ${ }^{34}$

Arthur D. Little, Inc. challenged the Cambridge regulation on constitutional grounds, alleging that local restrictions on federal defense contracts are precluded by the constitutional grant of war and defense powers to the federal government. ${ }^{35}$ The Supreme Judicial Court rejected the company's claim and upheld the regulation as a valid exercise of state police power. ${ }^{36}$

While acknowledging that the Constitution explicitly commits national defense to the federal government, the court held that "not every regulation which has some incidental effect on a defense program is invalid under the supremacy clause." ${ }^{37}$ In contrast to Fossella's reasoning that local concerns cannot impair national defense programs, the Massachusetts court held that incidental effects on defense programs do not justify constitutional invalidation and that a single ordinance would have only a "speculative and indirect impact"38 on national defense. In the extreme case in which all local governments banned the production of chemical warfare agents within their city limits, the court suggested that the Department of Defense could conduct chemical warfare research on its own military bases. ${ }^{39}$

The court also stated that the Cambridge regulation had a presumption of validity. Because one objective of a city government is "to preserve the health of the inhabitants"40 the court was unwilling to invalidate a health regulation unless it "conflicts with federal law or would frustrate the federal scheme" or unless the court determined that "from the totality of the circumstances that Congress sought to occupy the field to the exclusion of the States."

The court believed that federal law did not preempt the Cam-

34 Id. at 444 .

3 Id. at 448 .

36 Id. at 454 .

37 Id. at 449 (emphasis added).

${ }^{38}$ Id., quoting De Canas v. Bica, 424 U.S. 351, 355 (1976).

39 Id.

to Id. at $448-49$.

41 Id. at 450, quoting Metropolitan Life Insurance Co. v. Massachusetts, 471 U.S. 724, 747-48 (1985). 
bridge regulation for two reasons. First, the Department of Defense contract did not require that Arthur D. Little, Inc. conduct research on chemical agents in the city of Cambridge. ${ }^{42}$ Second, even if the Department of Defense contract required that Arthur D. Little, Inc. perform the contract in Cambridge, the court asserted that contracts between federal agencies and a private defense contractor do not "constitute[ ] Federal law for the purposes of the supremacy clause." ${ }^{\text {43 }}$ Although the court implied that Congressional legislation designed to foster private research on chemical warfare agents might represent "occupation of the field" preemption, the court rejected the argument that Department of Defense contracts could, by themselves, deny a city the "ability to protect its inhabitants" through health regulations. ${ }^{44}$

\section{B. Federalism and the Power to Control Defense and Interna- tional Relations.}

A number of Supreme Court cases have addressed the legitimacy of local actions that interfere with foreign affairs and national defense. These cases have subjected local and state regulation to scrutiny under two distinct analyses. One line of precedent investigates whether the regulations are barred by constitutional preclusion: that is, the Court has asked whether the constitutional grant to the federal government of authority over military matters and foreign affairs is alone sufficient to render invalid the challenged regulation. A second line of precedent investigates whether the local actions are barred by statutory preemption: that is, the Court has asked whether Congress has exercised its power over foreign affairs and the military in a manner that renders the local regulation impermissible.

As will be argued later in this comment, it is possible that what the Court has portrayed as constitutional preclusion arguments may be better understood in terms of statutory preemption analysis. On this view, the Court's concern with the constitutional scope of the foreign affairs powers is most defensible if read as an attempt to define a field-foreign affairs-which Congress and the President have intended to occupy through a variety of statutes and treaties. This view takes the Constitution not as a distinct source of barriers to state and local action but rather as a guide to

43 Id. at 452.

4 Id. at 451-52. 
the scope of national policy where the preemptive intent of the policy makers is ambiguous.

Of course, even if the Supreme Court's preclusion arguments do point to the Constitution as posing restraints independent of congressional or presidential action on state regulation of foreign policy matters, the preemption and preclusion lines of precedent are by no means logically inconsistent. This comment will present a framework capable of accommodating and giving content to the tests applied under both lines of precedent. Indeed, the Court itself has at times explicitly recognized that determining the validity of a local regulation touching upon foreign affairs requires the sequential application of the preemption and preclusion tests. ${ }^{45}$ Nonetheless, if the Court has applied the two lines of precedent as parts of one larger test, its articulation and application of that test has been so unclear and infrequent as to confuse lower courts. Those courts have tended either to treat preclusion and preemption as inconsistent alternatives for assessing local regulations related to the foreign affairs powers or to overstate the breadth of the preclusion test. ${ }^{46}$

1. Constitutional preclusion: cases holding that defense and foreign affairs are areas of exclusive federal power. Tarble's Case $^{47}$ provides an early example of judicial application of preclusion analysis to state laws interfering with the execution of federal defense powers. There, the Wisconsin Supreme Court granted a writ of habeas corpus for the release of a soldier from the United States army after the soldier's father complained that his son was a minor, ineligible to serve in the military until the age of eighteen years. The United States Supreme Court reversed on two distinct grounds.

The Court's more famous holding denied state courts the power to issue habeas writs to federal officers. ${ }^{48}$ But the Court, in

4 See De Canas v. Bica, 424 U.S. 351, 352-53 (1976) ("The question presented in this case is whether [the challenged statute] . . . is unconstitutional either because it is an attempt to regulate immigration and naturalization or because it is pre-empted under the Supremacy Clause.....").

46 The dramatically different reasoning of the Fossella and Arthur D. Little Inc. courts illustrate this problem. The dispute over the Provincetown Nuclear Free Zone, discussed in Section II.C, and the Supreme Court's own confusion in Clark v. Allen, 331 U.S. 503 (1947) and Zschernig v. Miller, 389 U.S. 429 (1968), discussed in Section II.B.2, also illustrate the problem.

4780 U.S. 397 (1871).

18 The opinion's second sentence declared that the question in the case was the general one of whether "any judicial officer of a State has jurisdiction to issue a writ of habeas corpus, or to continue proceedings under the writ when issued, for the discharge of a person 
an opinion not characterized by either clarity or economy, also offered a second, more narrow holding: state courts have no power to issue habeas writs to free soldiers from federal control because to do so would interfere with the national government's constitutional power over defense. ${ }^{49}$ The Court presented a classic constitutional preclusion argument in support of this narrower holding:

No interference with the execution of this power of the National government in the formation, organization, and government of its armies by any State official[ ] could be permitted without greatly impairing the efficiency, if it did not utterly destroy, this branch of the public service .... . [I]f soldiers could be taken from the army of the United States, and the validity of their enlistment inquired into by [state officials] . . . no movement could be made by the National troops without their commanders being subjected to constant annoyance and embarrassment .....

Tarble's Case thus arguably stands for the proposition that however compelling a state interest may be, including freeing those unlawfully detained, ${ }^{51}$ a state may not infringe upon the national power " 'to raise and support armies,' and the power 'to provide for the government and regulation of the land and naval forces." "\$2 The Court described as illegitimate any state legislative or judicial action questioning "how the armies shall be raised, . . . the age at which the soldier shall be received, . . . [or] the period for which he shall be taken ....."53

Almost seventy years later, in Hines $v$. Davidowitz, ${ }^{54}$ the $\mathrm{Su}$ -

held under the authority, or claim and color of the authority, of the United States, by an officer of that government." Id. at 402.

69 The opinion's first sentence declared that the question in the case was the narrow one of whether "a State court commissioner has jurisdiction; upon habeas corpus, to inquire into the validity of the enlistment of soldiers into the military service of the United States, and to discharge them from such service when, in his judgment, their enlistment has not been made in conformity with the laws of the United States." Id.

so Id. at 408.

${ }^{51}$ The Court acknowledged that the state judgment rested upon the "sacredness of the right to personal liberty, and 'the high searching, and imperative character' of the writ of habeas corpus." Id. at 400 .

${ }^{82}$ Id. at 408, quoting U.S.Const. art. I, $\S 8$, cls. 12,14. Whether Tarble's Case stands for its broad or its narrow holding is an issue of little importance to this comment. What is of interest is the case's reasoning rather than the scope of its precedential weight. It does seem odd, however, to allow the case to stand for its unnecessarily broad holding. See Anti-Fascist Committee v. McGrath, 341 U.S. 123, 154-55 (1951) (Frankfurter concurring)(courts should avoid deciding unnecessarily broad questions where narrower grounds are available).

s3 80 U.S. at 408.

34312 U.S. 52 (1941). 
preme Court considered whether states were precluded from acting in the area of foreign affairs ${ }^{55}$ in a non-military context. The Court answered the question in the affirmative and invalidated a Pennsylvania statute requiring every alien eighteen years of age or older to register with the state once a year. Justice Black applied the same sweeping federalism analysis used in Tarble's Case:

The Federal Government, representing as it does the collective interests of the forty-eight states, is entrusted with full and exclusive responsibility for the conduct of affairs with foreign sovereignties. "For local interests the several States of the Union exist, but for national purposes, embracing our relations with foreign nations, we are but one people, one nation, one power." Our system of government is such that the interest of the cities, counties and states, no less than the interest of the people of the whole nation, imperatively requires that federal power in the field affecting foreign relations be left entirely free from local interference. ${ }^{\mathrm{s}}$

Although subsequent Courts have erroneously interpreted Hines as resting solely on its statutory preemption reasoning, ${ }^{57}$ Justice Black's opinion, as this quote suggests, also rests on a constitutional preclusion analysis. The Court relies upon The Federalist, specifically numbers $3,4,5,42$ and 80 , as authority for the view that there is an "inherent danger of state action" in "all matters relating to foreign affairs." ${ }^{88}$ Federalist 42 , in particular, details a

${ }^{55}$ The Supreme Court defined the foreign affairs powers as also including the federal power over immigration, naturalization, and deportation. Id. at 62 .

${ }^{86}$ Id. at 63, quoting Chinese Exclusion Case, 130 U.S. 581, 606 (1889).

${ }^{57}$ See De Canas v. Bica, 424 U.S. 351, 355 (1976) ("[T]here would have been no need, in cases such as ... Hines v. Davidowitz . . . even to discuss the relevant congressional enactments in finding pre-emption of state regulation if all state regulation of aliens was ipso facto regulation of immigration, for the existence vel non of federal regulation is wholly irrelevant if the Constitution of its own force requires preemption of such state regulation"). Indeed, De Canas itself is less than precise about the federalism reasoning in Hines. See id. at 363 (recognizing that Hines may have been based "on the predominance of federal interest in the fields of immigration and foreign affairs").

Justice Black, who authored Hines, is partly responsible for the confusion surrounding the basis of the decision. He expressly claimed to leave open the question whether federal power in the field of foreign affairs "whether exercised or unexercised is exclusive." 312 U.S. at 62. Despite this qualification, he went on at length to show that the constitutional grant of authority over foreign relations involved "the one aspect of our government that from the first has been most generally conceded imperatively to demand broad national authority." Id. at 68 . While recognizing a narrow right of states to affect foreign relations, the opinion claimed that the state right was "subordinate to supreme national law" defined by constitutional constraints. Id.

ss Id. at 62 n.9. 
presumptive bar against state action in the field of foreign relations. James Madison opined that foreign relations is a federal power, for "[i]f we are to be one nation in any respect, it clearly ought to be in respect to other nations." The Court also quotes Thomas Jefferson, who wrote that the federal government does not share its responsibility for foreign affairs with the states: "My own general idea was, that the States should severally preserve their sovereignty in whatever concerns themselves alone, and that whatever may concern another State, or any foreign nation, should be made a part of the federal sovereignty." ${ }^{60}$ The Court's reliance upon these authorities reflects concern that the Constitution itself places limits upon state power over foreign affairs independently of any statute.

Justice Black's reasoning holds that state power "to restrict, limit, regulate, and register aliens as a distinct group is not an equal and continuously existing concurrent power of state and nation ...." The Constitution "restrict[s] to the narrowest of limits" any residual power which the states might retain to affect foreign relations. ${ }^{62}$

After the Court's discussion of the constitutional grant of the defense and foreign affairs powers to the federal government, the Court also held that the Pennsylvania statute was preempted by the federal Alien Registration Act of 1940. The Court reasoned that Congress intended to create a uniform naturalization and immigration law, freeing immigrants from "the possibility of inquisitorial practices and police surveillance" such as that required by the Pennsylvania statute. ${ }^{.3}$ The Court's conclusion that Congress intended to occupy the field of alien regulation may have been based on the Court's own extensive discussion of the need for one national policy in the field of foreign relations. ${ }^{64}$ The Court's iden-

so Id. at 63 n.11, quoting Federalist 42.

${ }^{60}$ Id., quoting Letter to Mr. Wythe (1787), 2 Correspondence and Miscellanies from the Papers of Thomas Jefferson 230 (1829).

${ }^{61}$ Id. at 68.

${ }^{62}$ Id.

63 Id. at 74.

64 The Court referred to Senator Connally's statement that the substitution of the Senate bill for the House bill and the eventual incorporation of the Senate bill into the framework of existing laws "make a harmonious whole." Id. at 72 n.34. The Senator's statement is, however, ambiguous as to the role of the states in alien registration. In dissent, Justice Stone argued that "compliance with the state law does not preclude or even interfere with compliance with the act of Congress." Id. at 81 . Given such compatibility, Justice Stone recommended that the test for invalidation be whether Congress has expressly foreclosed state action or has left evidence of such intent in the legislative record. Id. at 80. 
tification of this need for a single policy suggests a per se rule holding that when Congress has specifically addressed matters of national defense or foreign affairs, Congress also intended to occupy the field of regulation with respect to that matter. Under this analysis, state action would be foreclosed whenever Congress passes legislation unless Congress expressly enables state action. ${ }^{65}$

Although there are many reasons why the Court might have addressed both the constitutional preclusion and the statutory preemption issues, the Court relies on both constitutional federalism concerns and the extensive congressional action in the field of alien registration to form the basis for its opinion. The illegitimacy of the Court's reach toward the constitutional issue, when by its own account the statutory issue decided the case, underscores the Court's efforts to instruct the states that state efforts to influence foreign policies-either of the United States or foreign countries-are impermissible under our federal form of government. ${ }^{.6}$

In Zschernig $v$. Miller, ${ }^{67}$ the Supreme Court reaffirmed Hines's principle that states may not legislate on matters that affect foreign relations. An Oregon statute conditioned the claim of nonresident aliens to real or personal property on recognition in the foreign country of a reciprocal right of a United States citizen to take property on the same terms as a citizen of that country. An East German claimant argued that as applied the Oregon statute adversely affected only citizens of Communist or Socialist countries. The Court agreed and claimed that the Oregon legislature was attempting to induce foreign nations to frame their inheritance laws in the same way as did the state of Oregon. The Court invalidated this portion of the statute, which, as applied, involved the state in "foreign affairs and international relations-matters which the Constitution entrusts solely to the Federal Government."68

The Court's invalidation of the Oregon inheritance law relied upon two constitutional arguments. First, by manifesting a cold war attitude, the Oregon statute and the judicial opinions interpreting it conflicted with a specific U.S. foreign policy of negotia-

${ }^{85}$ Compare Maryland v. Louisiana, 451 U.S. 725, 746 (1981) (preemption analysis "starts with the basic assumption that Congress did not intend to displace state law").

${ }^{68}$ See John Norton Moore, Federalism and Foreign Relations, 1965 Duke L.J. 248, 297 98 ("II]n order to insure implementation of foreign policy at the national level, it is imperative that there be substantial federal control over independent state action taken pursuant to the police power which affects foreign relations").

67 389 U.S. 429 (1968).

${ }^{B s}$ Id. at 436. 
tion with East Germany. ${ }^{69}$ Second, the Oregon statute was invalid, even in the absence of a treaty or Congressional action. ${ }^{70}$ In his concurring opinion, Justice Stewart emphasized that even if the Oregon statute was consistent with the conduct of foreign relations,

that is not the point. We deal here with the basic allocation of power between the States and the Nation. Resolution of so fundamental a constitutional issue cannot vary from day to day with the shifting winds at the State Department. Today, we are told, Oregon's statute does not conflict with the national interest. Tomorrow it may. But, however that may be, the fact remains that the conduct of our foreign affairs is entrusted under the Constitution to the National Government, not to the probate courts of the several States. ${ }^{71}$

The Court does not appear to be influenced by the effect of Oregon probate courts on foreign affairs. Indeed, the Solicitor General, as amicus curiae, argued that the Oregon escheat statute did not interfere with the federal conduct of foreign relations. ${ }^{72}$ The cold war attitudes reflected in Oregon probate court decisions were not necessarily in opposition to a U.S. foreign policy which was also characterized by cold war attitudes. The Court's opinion seems to adopt a different test than that of effects; the statute was invalid because it required probate courts to evaluate the ideology of foreign governments under the guise of analyzing reciprocity in laws governing property claims.

Lastly, constitutional federalism issues also arose in Plyler $v$. $D o e,{ }^{73}$ an equal protection challenge to a state statute withholding funds from local school districts for education of children not legally admitted into the country. In the course of applying heightened scrutiny to the statute, the Court rejected an argument that

${ }^{69}$ Id. at 440 .

70 Id. at $436,441$.

${ }^{71}$ Id. at 443 (Stewart concurring). Justice Stewart's argument cannot, however, be entirely correct. In other areas in which the Constitution affirmatively grants the federal government regulatory power, such as the commerce power, the states are free to regulate consistently with federal policy unless federal policy forecloses state action. Where the federal scheme does not displace the state scheme, as in the law of corporations, the constitutionality of state regulations does shift according to the "winds" of the federal regulatory agency. See, e.g., CTS Corp. v. Dynamics Corp. of America, 107 U.S. 1637, 1644 (1987) (scope of state power to regulate corporate takeovers depends on whether the state regulation conflicts with existing SEC regulations).

72389 U.S. at 443 (Stewart concurring).

${ }^{73} 457$ U.S. 202 (1982). 
it should defer to the political branches, including state legislatures, with respect to immigration matters. The Court justified its refusal to defer by claiming that " $[t]$ he States enjoy no power with respect to the classification of aliens . . . . This power is "committed to the political branches of the Federal Government." "74 The Court treated alienage as an extension of foreign relations powers, ${ }^{75}$ thus implicating the need, identified by Hines, for one national policy in our relations with other countries.

The breadth of the Court's reasoning in Plyler is striking. Despite its decision in Zschernig, the Court could have disposed of the equal protection claim in Plyler while treating the alienage powers like the commerce powers, over which both the federal and state governments share an interest. In Zschernig, the Oregon statute regulated a nonresident's claim to property according to the acts of a foreign government. But in Plyler, the conduct of a foreign government had no effect upon the rights of illegal alien children under the statute. The treatment of aliens in Plyler thus resembles the social regulation of American citizens rather than an exercise of foreign affairs powers. That the Plyler Court did not compare the commerce and immigration powers illustrates the Court's allegiance, at least on some occasions, to the notion that the enumeration of federal powers forecloses all state action, whether or not the federal government has acted through a treaty or statute. Of course, a less strict application of preclusion analysis in Plyler might well have done the state no good, since treating the immigration power as analogous to the commerce power would not have led the Court to defer to the legislature in circumstances where it would otherwise apply heightened scrutiny.

2. Statutory preemption: cases determining whether local actions affecting defense and foreign affairs are barred by Congressional statute.or treaty. There are three branches of preemption analysis. The first provides that a state law is preempted by a federal statute or treaty if Congress expressly mandates the preemption of state law. The second holds state law preempted to the extent it conflicts with federal law or federal policy. The third holds state law preempted when a federal statute or treaty evinces a con-

74 Id. at 225, quoting Mathews v. Diaz, 426 U.S. 67, 81 (1976).

${ }^{75}$ The Court explained its treatment of alienage as a foreign affairs power as follows: "The Constitution grants Congress the power to 'establish an uniform Rule of Naturalization.' Art. I, § 8, cl. 4. Drawing upon this power, under its plenary authority with respect to foreign relations and international commerce, and upon the inherent power of a sovereign to close its borders, Congress has developed a complex scheme governing admission to our $\mathrm{Na}$ tion and status within our borders." Plyler, 457 U.S. at 225. 
gressional intent to occupy the field of the challenged state regulation. ${ }^{76}$

The Court has applied preemption analysis to state laws that affect foreign affairs and matters of national defense. The analysis does not necessarily conflict with the preclusion line of cases discussed above. If the Court invalidates the law on the basis of preemption, but never reaches the constitutional question of state preclusion, the cases are entirely consistent. Moreover, if the Court upholds a state law that affects foreign affairs and national defense, the Court's preemption analysis can still comport with the preclusion analysis so long as the preclusion bar is understood to reach some, but not all, local regulations touching upon foreign affairs. If, however, one accepts the sweeping preclusion arguments quoted in the preceding subsection-arguments that would exclude state power entirely from the spheres of foreign affairs-then the preclusion and preemption tests cannot be reconciled.

In United States $v$. Pink, ${ }^{77}$ the Supreme Court reversed a New York property settlement ruling because the property distribution conflicted with the 1933 Litvinov Assignment, a federal treaty with the Soviet Union. The treaty assigned all Soviet claims relating to property held in the United States to the United States government. Yet the New York state courts permitted the Superintendent of Insurance of New York to distribute assets of an insurance company nationalized by the Soviet Union without recognizing the claim of the United States as successor to the Soviet interest in the company.

The Superintendent responded to the U.S. complaint by contending that title to the funds never vested with the Soviet government and thus could not pass to the U.S. government via the Litvinov Assignment. On a motion for summary judgment, the New York Supreme Court dismissed the government's complaint on the merits. The U.S. Supreme Court characterized the New York state court actions as a "rejection of a part of the policy underlying recognition by this nation of Soviet Russia." the state court's actions, claiming, "Such power is not accorded a State in our constitutional system. To permit it would be to sanction a dangerous invasion of Federal authority. For it would 'imperil the amicable relations between governments and vex the

${ }^{78}$ See Brown v. Hotel Employees, 468 U.S. 491, 501 (1984); Louisiana Public Service Comm'n v. F.C.C., 476 U.S. 355, 368 (1986).

77 U.S. 203 (1942).

${ }^{78}$ Id. at 233. 
peace of nations." "79 In order to uphold the U.S. foreign policy, as expressed in the Litvinov Assignment, the Court held that the right to the funds became vested in the Soviet government as the successor to the nationalized insurance company and that this right had passed to the United States government under the Litvinov Assignment. ${ }^{80}$

The scope of the Court's opinion is peculiarly narrow, in light of some of the Court's other opinions on the reach of the foreign affairs powers, and asks only whether the New York state courts has properly complied with the Litvinov Assignment. This test is one which implicitly permits states to affect directly America's relations with foreign countries, provided that the state action appropriately mirrors the federal policy. The Court's judgment is triggered by New York's rejection of the federal policy, not by the state's determination of Soviet property rights. ${ }^{81}$ The Court does not hold-in a manner which would parallel the decision in Tarble's Case - that the property settlements of foreign companies are the exclusive jurisdiction of federal courts.

Neither can Clark v. Allen ${ }^{82}$ and De Canas v. Bica ${ }^{83}$ be reconciled with the more extreme aspects of the preclusion precedents that bar states from regulating in a manner that affects defense policies and foreign relations. Both cases held that federal law did not preempt state statutes which affected foreign relations.

In Clark v. Allen, twenty-one years before Zschernig, the Court upheld a California probate code, virtually identical to the Oregon probate statute, ${ }^{84}$ as consistent with the 1923 Treaty of Friendship with Germany. Because the treaty was not applicable to claims of personal property, the Court also considered the constitutional challenge. But in contrast to Zschernig, Clark treated the claim that California was seeking to promote the right of American citizens to inherit abroad (by offering aliens reciprocal inheritance rights in California) as "farfetched."

Clark held that a state law which has "some incidental or indi-

79 Id., quoting Oetjen v. Central Leather Co., 246 U.S. 297, 304 (1918).

so Id. at 234.

${ }^{81}$ See also Omaya v. California, 332 U.S. 633 (1948) (California cannot erect obstacles to prevent immigration of people whom Congress has authorized to come into the country).

3231 U.S. 503 (1947).

324 U.S. 351 (1976).

84 Like the Oregon probate code in $Z$ schernig, the California probate code contained a reciprocity provision. The statute made the right of a non-resident alien to acquire property depend on the right of American citizens to do so in the country of which the alien was an inhabitant or citizen.

${ }^{85}$ Id. at $516-17$. 
rect effect in foreign countries" is valid unless it conflicts with an "overriding federal policy," as evidenced by treaty or statute. ${ }^{86}$ This rule conflicts directly with the rule the Court later adopted in Zschernig, but only Justice Stewart, in his concurring opinion, formally rejected Clark. ${ }^{87}$

Similarly, in De Canas v. Bica, the Court refused to invalidate a California statute that prohibited an employer from knowingly employing an illegal alien, if such employment would have an adverse effect on lawful resident workers. Justice Brennan claimed that the California legislation was problematic only under preemption, not preclusion, analysis: "the Court has never held that every state enactment which in any way deals with aliens is a regulation of immigration and thus per se pre-empted by this constitutional power, whether latent or exercised."88 Justice Brennan's reasoning rejects the broad rhetoric of the Hines decision, which argued that the regulation of immigration is included among the exclusive federal powers over foreign affairs.

In its discussion of the statutory issue, the Court held that the Farm Labor Contractor Registration Act indicated that Congress did not intend to occupy the field of the regulation of illegal alien employment, but the Court was uncertain as to whether the California statute undermined the federal policy embodied in the Immigration and Nationality Act. ${ }^{88}$ Although the Court recognized that California's efforts to restrict the employment opportunities of illegal aliens seemed to comport well with the federal policy defining who can lawfully enter the country, the Court nonetheless remanded the case to determine whether the California statute would frustrate the full purposes of Congress.90

\section{Modern Courts are Without Guidance.}

The disparate resolutions of Fossella and Arthur D. Little, Inc. reflect different premises about the scope of the federal power to conduct foreign relations and to provide for national defense. Fossella is based on the proposition that any state action in the field of national defense necessarily interferes with the exclusive

86 Id. at 517.

${ }^{87}$ Zschernig, 389 U.S. at 443 (Stewart concurring).

88 424 U.S. at 354-55 (emphasis in original).

s8 Id. at 361-63. The Farm Labor Contractor Registration Act provided that states may, "to the extent consistent with federal law, regulate the employment of illegal aliens." Id. at 361.

${ }^{80}$ Id. at $363-65$. 
federal power to provide for the common defense. In contrast, $A r-$ thur $D$. Little, Inc. assumes that the state police power reaches matters that may affect the concurrent federal power over national defense, unless specifically preempted by federal statute or treaty.

The controversy surrounding the Provincetown, Massachusetts NFZ by-law is another example of the confusion caused by the Supreme Court's uncertain jurisprudence in this area. In 1985, then state Attorney General Francis Bellotti overruled Provincetown's NFZ by-law as an unconstitutional infringement upon the right of Congress to provide "for the common defense." However, in a June 5, 1987 letter to the Provincetown town clerk, Assistant Attorney General Steven Goldberg wrote that "[i]n light of Arthur D. Little, Inc. . . . there does not appear to be a facial conflict between the [Provincetown] by-law and the U.S. Constitution or any federal statute or regulation."92 The few relevant commentaries offer little guidance on the federalism problems raised here. ${ }^{93}$

Without a theoretical framework for assessing the scope of the national defense or foreign affairs powers, state courts may rule with unfettered discretion upon the validity of state statutes which touch upon these federal powers, upholding those statutes which the courts favor and invalidating those which they do not.

\section{The Foreign Affairs Clauses as Express and Implied RESTRICTIONS UPON LOCAL REgUlation}

Where Congress has spoken clearly about the preemptive significance of its foreign affairs and military policy, determining the limits upon state and local regulation is easy, both as a theoretical and as a practical matter. But when Congress is silent or speaks ambiguously, two problems arise. First, to what extent did Congress wish, through one or all of its statutory enactments, to pre-

91 Massachusetts Attorney General Approves Provincetown By-Law, New Abolitionist 3 (Oct. 1987). Similarly, Bellotti claimed that the Amherst, Massachusetts NFZ "would result in the 'balcanization' of the nation ... [I]t would result in the federal government losing control of its foreign policy and would deprive Congress of its war-making power." Bennett, The New Abolitionists 167 (cited in note 3).

22 Letter from Steven Goldberg to Sheila Silva, Provincetown Town Clerk (June 5, 1987)(on file with the University of Chicago Law Review).

${ }^{93}$ See William N. Weaver, Jr., et al., The Legality of the Chicago Nuclear Weapon Free Zone Ordinance, 17 Loyola U.L.J. 553, 574-75 (1986)(discussing in three paragraphs the war powers issues raised by NFZs); Note, State and Local Anti-South Africa Action as an Intrusion Upon the Federal Power in Foreign Affairs, 72 Va.L.Rev. 813 (1986) (assuming that the foreign commerce clause would invalidate local South African divestment legislation). 
empt state laws arguably conflicting with federal policy or to occupy the field of foreign affairs? Second, to what extent does the Constitution impose limitations on state action in this area independent of statutory or executive action?

Both questions point to a more general issue: what are the appropriate "background rules" limiting state regulation of foreign affairs when there is vigorous national activity in that area but no clear national pronouncement on the scope of state authority? The section looks first at the existing regulatory framework for the federal nuclear defense program and multinational disarmament. Second, the section examines the structural justifications for a "dormant foreign affairs" analysis that would place constitutional limitations on state regulation. Third, the section turns to dormant commerce clause doctrine as a source of distinctions to guide the Court in the constitutional preclusion inquiry.

\section{A. Statutory Preemption: The Federal Framework for Nuclear Armament and Disarmament.}

The courts have historically accorded national defense determinations extraordinary deference. ${ }^{94}$ This may be due, in part, to the inherent secrecy surrounding important intelligence information, such as the locus of major foreign threats or the strategic placement of nuclear weapons. But also, the Court has accepted, without question, that a national, deliberative legislative body is better equipped than the federal courts to gather and analyze defense information. ${ }^{85}$

However, in order for the courts to defer to national defense and foreign policy, the political branches must clearly articulate their program goals. Yet while Congress and the President often detail the purpose of their policies, they are generally ambiguous as to the role of the states in these policies. Numerous Presidential

${ }^{94}$ See, e.g., Korematsu v. United States, 323 U.S. 214 (1944) (upholding the internment of Japanese-Americans during World War II to prevent espionage and sabotage); United States v. O'Brien, 391 U.S. 367 (1968) (affirming draft card burning conviction during the Vietnam War); Rostker v. Goldberg, 453 U.S. 57 (1981) (upholding male-only draft registration because Congress' policy excluded women from combat). But see New York Times Co. v. United States, 403 U.S. 713 (1971) (vacating a stay of publication order governing the Pentagon Papers).

${ }^{85}$ See Gilligan v. Morgan, 413 U.S. 1, 10 (1973) (" $[I] t$ is difficult to conceive of an area of governmental activity in which the courts have less competence. The complex, subtle, and professional decisions as to the composition, training, equipping, and control of a military force are essentially professional military judgments, subject always to civilian control of the Legislative and Executive Branches.") (emphasis in original). 
orders, Congressional statutes and agency actions by the Departments of State and Defense comprise the field of national defense and determine whether state regulation of nuclear weapons contractors is preempted by federal law. This subsection describes some of the federal programs which define our present nuclear defense policy.

1. The Atomic Energy Act of 1954. The Atomic Energy Act of 1954 established the present system of federal regulation over atomic energy. ${ }^{86}$ The Act was passed in order to provide for the private development of atomic energy for peacetime uses. ${ }^{97}$ The Act and its subsequent amendments created the Nuclear Regulatory Commission and the Energy Research and Development Authority to produce special nuclear material and to license production facilities. The Act also established a Military Liaison Committee to consult with the Department of Defense in matters relating to military applications of atomic weapons. ${ }^{98}$

As originally enacted, the Atomic Energy Act did not expressly accord the states a role in the regulation of nuclear power plants or weapons. In 1959, however, Congress amended the Act in order to provide for greater cooperation between the states and the Nuclear Regulatory Commission in the regulation of "peaceful" uses of nuclear energy. ${ }^{98}$ The Act authorizes state regulation only "for purposes other than protection against radiation hazards."

Although Congress has amended those portions of the Act which regulate the military application of Atomic Energy, ${ }^{101}$ there is no express state role in the regulation of military applications of atomic energy. In contrast, the 1959 amendments to the Act increased the accountability of the Commission to the federal government in two ways. First, the Act now authorizes the Nuclear Regulatory Commission to conduct experiments on the military application of atomic energy under the direction of the President and the Department of Defense. ${ }^{102}$ Second, the Act authorizes the

${ }^{96} 42$ U.S.C. \& 2011 et seq. (1982). For an extensive discussion of the legislative history and amendments to the Atomic Energy Act, see Arthur Murphy and D. Bruce La Pierre, Nuclear "Moratorium" Legislation in the States and the Supremacy Clause: A Case of Express Preemption, 76 Colum.L.Rev. 392 (1976).

${ }^{97}$ Atomic Energy Act of 1954, S.Rep.No. 1699, 83rd Cong., 2d Sess. (1954) in 1954 U.S.Code Cong. \& Admin.News 3456, 3458.

8842 U.S.C. \$ 2037.

99 Act of September 23, 1959, Pub.L.No. 86-373, 73 Stat. 688, codified as amended, 42 U.S.C. $\$ 2021$ (1982).

${ }_{100} 42$ U.S.C. $\$ 2021(\mathrm{k})$.

101 Act of July 2, 1958, P.L. 85-479, codified as amended, 42 U.S.C. $\$ 2121$ (1982).

${ }^{202} 42$ U.S.C. $\S 2121(\mathrm{a})$-(b). 
Department of Defense to refer all policy disagreements between the Defense Department and the Nuclear Regulatory Commission directly to the President, whose decisions are final. ${ }^{103}$

The scope of the states' regulatory authority over nuclearpowered electricity generation was addressed in two Supreme Court decisions, Pacific Gas \& Elec. v. Energy Resources Comm' $n^{104}$ and Silkwood v. Kerr-McGee Corp. ${ }^{105}$ Together, these decisions stand for the proposition that the Atomic Energy Act preempts state regulation of nuclear safety concerns but does not preempt state regulation of nuclear power plants. Neither decision addresses the scope of state power to regulate other aspects of nuclear technology, such as nuclear weapons contractors.

In Pacific Gas \& Elec., the Court held that the Atomic Energy Act did not preempt a California statute which conditioned the construction of nuclear plants on the finding by a state commission that adequate storage facilities and means of disposal were available for nuclear waste. Justice White, writing for the majority, claimed that the Atomic Energy Act allowed for dual regulation of atomic plants by both the federal and state governments. While the federal government maintains complete control over the regulation of radiation safety, the states have authority to determine their "need for additional generating capacity, the type of generating facilities to be licensed, land use, ratemaking, and the like."106 The majority upheld the California statute, accepting California's avowed purpose of responding to the potential economic costs of nuclear powered electricity caused by a lack of waste storage space. The Court's analysis suggests that many radiation risks have an economic character to them and are statutorily within a state's power to regulate. ${ }^{107}$

Similarly, the Court in Silkwood upheld an Oklahoma punitive damages statute which imposed damages for radiation injuries against the claim that the Atomic Energy Act forecloses all state remedies related to nuclear safety. The Court's analysis follows from its holding in Pacific Gas \& Elec. that Congress did not preempt state regulation of nuclear power in matters other than nuclear safety. In Silkwood, the Court explained that the Nuclear Regulatory Commission is vested with exclusive authority over nu-

103 Id.

104461 U.S. 190 (1983).

105464 U.S. 238 (1984).

108461 U.S. at 212.

107 Id. at 212-14, 216, 222. 
clear safety matters, but the Act does not bar state negligence or strict liability laws that permit plaintiffs to recover for radiation injuries. ${ }^{108}$ Together, Pacific Gas \& Elec. and Silkwood suggest that, since a state can easily give desired regulations an economic rather than a safety-related rationale, the Act does little to preempt local regulation of commercial uses of nuclear energy.

Although there is no express indication that Congress did not expand the role of states in the regulation of all industries which use nuclear material, the legislative history of $\S 2021$ suggests that Congress did not extend the scope of state regulation to nuclear weapons manufacturers as well as to nuclear-powered electric plants. The adoption of $\S 2021$ followed the introduction in twenty-four state legislatures of state bills which would have restricted or prohibited the development and use of nuclear power plants generating electric energy for commercial distribution. ${ }^{108}$ Section 2021 responded to these state measures and is positioned in the portions of the Act which regulate nuclear power plants, not the portions which regulate the military uses of nuclear materials.

In addition, the legislative history of the Atomic Energy Act itself suggests that Congress did not wish to share the responsibility for nuclear weapons regulation with the states. By 1954, nuclear weapons had replaced a large standing army as the basis of America's national defense program. ${ }^{110}$ Although the 1954 Act encouraged the construction of atomic power plants, peaceful uses of atomic energy were "subject at all times to the paramount objective of making the maximum contribution to the common defense and security." 111 The Act contains several explicit safeguards for national defense, such as $\$ 2138$ which allows the Nuclear Regulatory Commission to recapture any special nuclear material and enter into any plant or facility whenever the Congress declares a state of war or national emergency. ${ }^{112}$ Even the 1959 amendment to the Act, whose "point . . . was to heighten the States' role,"113 recognized only "the interests of the states in the peaceful uses of atomic energy." "114 In light of the provisions subordinating domestic interests to foreign policy concerns, there is no reason to believe

\footnotetext{
${ }^{103} 464$ U.S. at 256.

${ }^{109}$ Murphy and La Pierre, 76 Colum.L.Rev. at 392 (cited in note 96).

110 See S.Rep.No. 1699, in 1954 U.S.Code Cong. \& Admin.News at 3458 (cited in note

11142 U.S.C. § 2011 (a).

11242 U.S.C. $\$ 2138$.

${ }^{113}$ Pacific Gas \& Elec., 461 U.S. at 209.

11442 U.S.C. $\S 2021$ (a)(1) (emphasis added).
} 97). 
that an extension of the state regulatory power over nuclear weapons manufacturers would comport with the national defense concerns which also shaped the Atomic Energy Act.

2. The Arms Control and Disarmament Act. The Arms Control and Disarmament Act ${ }^{115}$ created the Arms Control and Disarmament Agency to provide the President and Congress with scientific, political, military, and technological information upon which an arms control policy would be based. ${ }^{116}$ The legislative history of the Act illustrates that two concerns shaped Congressional support for the Agency. First, both President Eisenhower and Congress perceived that an arms control and disarmament policy required centralized management, accountable directly to the highest level of the national government. ${ }^{117}$ While the Act does not expressly foreclose state efforts to hasten nuclear disarmament, the Congressional testimony reveals that Congress did not believe that the states retained any power to affect independently national security policy. Neither did Congress believe that the Arms Control Agency would itself set national security policy. Both the President and Congress conceived of the Arms Control Agency as an instrument of the President in policy formulation and international negotiation. ${ }^{118}$ It seems incomprehensible that a Congress concerned about the possibility that a federal arms control agency might interfere with federal defense policy also would have believed that state or local governments could regulate the size of the federal nuclear arsenal.

Second, the Arms Control and Disarmament Act responded to Congressional concerns that unwise nuclear disarmament could endanger the nation's security. The House Report indicates that Congress would not countenance disarmament "when such a course will endanger our security."118 Although it might generally be said that if Congress has not enacted legislation, there is no statutory bar to state action, this principle does not hold true with

\footnotetext{
115 Pub.L.No. 87-297, 75 Stat. 631 (1961), codified, 22 U.S.C. $\S 2551$ et seq. (1982).

11822 U.S.C. $\$ 2551$.

117 The policy statement of the Act proclaims:

Arms control and disarmament policy, being an important aspect of foreign policy, must be consistent with national security policy as a whole. The formulation and implementation of United States arms control and disarmament policy in a manner which will promote the national security can best be insured by a central organization charged by statute with primary responsibility for this field.

118 Arms Control and Disarmament Act, H.Rep.No. 1165, 87th Cong., 1st Sess. (1961), 1961 U.S.Code Cong. \& Admin.News 2903, 2904.

218 Id. at 2903.
} Id. 
respect to nuclear disarmament policy. When the President has not negotiated a multilateral nuclear disarmament policy, or if Congress does not approve the treaties the President has negotiated, there is, in effect, a policy not to disarm. Thus, local efforts to disarm necessarily conflict with a federal policy to maintain the size of the nuclear arsenal.

This interpretation of the import of the federal government's failure to disarm is supported by the legislative history of the Arms Control and Disarmament Act. Secretary of State Dean Rusk remarked:

Given the shape and nature of the world today, wise policy requires that we maintain a military force sufficient to deter or meet aggression wherever it may occur. Yet the present situation and indeed, our own basic policies require that we make strong, patient and sincere efforts to do everything possible to create conditions under which nations can safely reduce their armaments and thereby alleviate the dangers inherent in an uncontrolled arms race.

It is essential that both of these policies be pursued. To pursue one of them to the exclusion of the other is to court disaster. But taken together, they provide the most promising way by which we can insure our survival. ${ }^{120}$

Local NFZs that seek to pressure American companies to halt nuclear weapons production could jeopardize the federal defense strategy of reducing our nuclear arsenal exclusively through negotiated treaties, thus thwarting national policy efforts aimed at long term, multinational nuclear reduction.

3. Defense Procurement Improvement Act of 1985. The Defense Procurement Improvement Act ${ }^{121}$ is a recent federal statute supporting a national defense policy based in part on nuclear weapons. The Act's policy statement provides that "it is in the interest of the United States that property and services be acquired for the Department of Defense in the most timely, economic and efficient manner." 22

It seems, however, that this Act has little or no preemptive effect with respect to Nuclear Free Zones. The Act expressly provides that Congress intended to permit the Executive, through the Department of Defense, to share procurement authority with re-

${ }^{220}$ H.Rep.No. 1165, 1961 U.S.Code Cong. \& Admin.News 2908 (cited in note 118).

12110 U.S.C. \& 2301 (1985).

12210 U.S.C. $\S 2301$ (a). 
spect to national defense policy. If Congress had delegated broad authority to the Department of Defense to preempt state law and engage in rulemaking, Department of Defense rules would have preemptive effect against the states. ${ }^{123}$ The Defense Procurement Improvement Act, however, provides only for proprietary or management decisions and does not state that purchasing decisions have preemptive effect against state actions. Nor does the Act convey any substantive rulemaking authority to the Department of Defense to preempt state actions which might erode the industrial base of the country. On the contrary, the Act provides that it is Congress that should "promote the attainment and maintenance of an essential capability in the defense industrial base and the capability of the United States for industrial mobilization."124

4. The General Federal Commitment to Nuclear Weapons: Occupying a Field? There are arguably three reasons for maintaining the American strategic nuclear forces: deterring attacks on the United States; deterring attacks on allies; and supporting U.S. foreign policy. ${ }^{125}$ Obviously, there are numerous federal actions affecting the pursuit of these goals, including determinations of the size of NATO ground forces ${ }^{128}$ and agreements between the U.S. and NATO countries for the provision of weapons. ${ }^{127}$ A discussion of all these programs exceeds the scope of this comment. However, it is generally uncontroversial that the federal government is presently committed to a defense program with an essential nuclear weapons component.

The issue that these numerous federal programs present is whether Congress intended to allow the states to regulate with respect to federal foreign affairs and national defense policy. Analytically, this question can be conceived of as implicating either the second or third branch of the Court's preemption doctrine. If Congress has determined that the federal government alone has authority to set policy in this area, then state intrusion both conflicts with a federal policy and trespasses upon a field occupied by the

${ }^{123}$ For a critique of the preemptive effect of some agency rules, see Susan Bartlett Foote, Administrative Preemption: An Experiment in Regulatory Federalism, 70 Va.L.Rev. 1429 (1984).

12410 U.S.C. $\$ 2301(b)(4)$.

${ }^{25}$ Carnegie Endowment for International Peace, Challenges for U.S. National Security: Nuclear Strategy Issues for the 1980's 34 (1982).

${ }^{228}$ Andrew J. Goodpaster, For the Common Defense 109 (1977) (nuclear weapons equalize the superior ground forces which the Warsaw Pact could employ against NATO countries).

${ }^{127}$ Id. at 127 (U.S. contributes to the aggregate tactical nuclear capability of NATO by providing, under U.S. custody, the weapons which NATO allies utilize). 
federal government. The question is which background rule makes the most sense as a matter of statutory interpretation: (1) a rule that provides that the states cannot legislate in a manner that affects foreign affairs and national defense unless Congress has passed enabling legislation, or (2) a rule that leaves the states free to legislate according to their traditional police powers provided that their actions are not expressly preempted by Congress? The legislative history of the several federal statutes involved is ambiguous as to which background rule Congress would prefer. The legislative history neither accords nor expressly denies the states a role in the regulation of nuclear weapons.

Ambiguities in Congressional intent might be resolved through a particular reading of the constitutional preclusion cases discussed in Part II.A. Hines v. Davidowitz arguably uses constitutional interpretation as an adjunct to preemption analysis: it suggests that the preemptive effect of federal statutes might be measured by interpretation of the constitutional allocation of responsibility over foreign affairs. ${ }^{128}$ The express grant of power to the federal government over defense and foreign affairs on this view both legitimizes federal actions pursuant to those powers and may, where Congressional intent is ambiguous, define the scope of federal programs. This method of statutory interpretation recasts the constitutional restrictions articulated in the next two sections as statutory rather than constitutional in character. The difference may not matter much: whether the background rules in play are regarded as constitutional or statutory, Congress may act to alter the scope of state power.

\section{B. Constitutional Preclusion as a Limit to State Regulation.}

Two sorts of constitutional limitations-express restrictions and implied restrictions-may be relevant to the state regulation of foreign affairs and national defense. The express limitations have raised few challenges and include restrictions on the power of the states to enter treaties, to keep troops or ships of war in time of peace, and to engage in war unless actually invaded. ${ }^{129}$ More

128 The Court has applied this strategy, albeit inconsistently, to determine whether a federal statute occupies a field. For example, in Florida Lime and Avocado Growers, Inc. v. Paul, 373 U.S. 132, 143-44 (1963), the Court reasoned that Department of Agriculture marketing orders, passed pursuant to the Agricultural Adjustment Act, did not occupy the field of regulation of fruits because, under Cooley v. Board of Port Wardens, 53 U.S. 299 (1851), the maturity of avocados was not a likely candidate for exclusive federal control and was not a subject admitting only of national supervision.

${ }_{129}$ U.S.Const. art. I, $\S 10$. See Louis Henkin, Foreign Affairs and the Constitution 228- 
controversial is the question of whether these express restraints are supplemented by implied restraints, and if so, what those restraints are.

1. The rationale for implied restrictions on state power to regulate foreign affairs and national defense. A strict textual interpretation of the Constitution might suggest that because the Constitution expressly restricts state action in some matters of foreign affairs and national defense, the courts should not imply additional limitations on state power in this area. However, the Court has rejected such a literal analysis of the foreign relations and national defense powers.

The Court has long recognized that the foreign affairs powers are structural in nature and not derived from a strict textual interpretation of the Constitution. ${ }^{130}$ Federal powers over foreign relations include all powers necessary both to define the country with respect to other sovereign powers and to defend the country in the event of aggression. On the basis of this premise, the Court in U.S. v. Curtiss-Wright Corp. stated that even if the powers to engage in war and maintain diplomatic relations with other countries were not in the Constitution, they would nonetheless have been vested in the federal government as "necessary concomitants of nationality."131

As such considerations expand the power of the federal government over foreign relations beyond expressly enumerated powers, functionalist arguments suggest that the powers of the states to affect foreign affairs and national defense are far narrower than those express restrictions in Article I, $\S 10$. The affirmative grant to the federal government of the power to conduct foreign relations was intended to create, and has in fact created, a strong national government which singly represents the American people in relations with other nations.

With respect to the conduct of foreign relations, the rationale for a strong national government is that large deliberative bodies keep the states out of war. ${ }^{132} \mathrm{John}$ Jay wrote that the national government, "will be more temperate and cool" than the states, a difference which would result in "fewer just causes of war."133 Jay believed that a national government is necessary "to put and keep

34 (1972).

${ }^{230}$ See U.S. v. Curtiss-Wright Corp., 299 U.S. 304 (1936).

131 Id. at 318.

${ }^{232}$ See Federalist 3-5.

${ }^{133}$ Federalist 3, in Clinton Rossiter, ed., The Federalist Papers 41, 45 (1961). 
[the states] in such a situation as, instead of inviting war, will tend to repress and discourage it."134 Similarly, Alexander Hamilton favored a strong national government, fearing that a single state could discount the interests of all the states by pursuing an ill-planned, unwise war. Hamilton wrote:

the peace of the WHOLE ought not to be left to the disposal of a PART. The Union will undoubtedly be answerable to foreign powers for the conduct of its members. And the responsibility for an injury ought ever to be accompanied with the faculty of preventing it. ${ }^{135}$

A related rationale for a strong national government is that it deters foreign aggression through its large size and greater resources, but this deterrent effect is weakened if the member states act in an uncoordinated fashion. ${ }^{136}$ State action also has the potential of impairing the operation of federal diplomatic and strategic relations. ${ }^{137}$ Foreign nations may be unable to perceive that state A's actions are not national policy and do not represent a departure from an American treaty or official statements. And because the costs of diplomatic blunders are largely borne by the nation as a whole, the states have inadequate incentive to consider the effects of their actions on foreign relations. For example, when the federal government agrees to provide nuclear missiles in support of our NATO allies, the delivery date reflects upon the national commitment. If local governments succeed in delaying the production of nuclear weapons, or thwart nuclear weapons production entirely, it is not state but federal relations with foreign countries which are jeopardized. ${ }^{138}$

2. Arguments for vigorous state activity do not support state intrusion into foreign relations. Recently, several scholars have argued for greater recognition of state autonomy. ${ }^{139}$ Although they have not expressly applied their arguments to the foreign relations and national defense fields, ${ }^{140}$ their general arguments on behalf of

${ }^{234}$ Federalist 4, in The Federalist Papers at 45,47 (emphasis in original).

${ }^{136}$ Federalist 80 , in The Federalist Papers at 475, 476 (emphasis in original).

${ }^{138}$ Federalists 4 and 5, in The Federalist Papers at 45, 47, 49; and at 50, 53.

${ }^{137}$ Federalist 80 (Hamilton), in The Federalist Papers at 475, 475.

${ }^{238}$ See Gibbons v. Ogden, 22 U.S. 1, 100 (1824) (Johnson concurring) ("The states are unknown to foreign nations.....").

139 See Michael W. McConnell, Federalism: Evaluating the Founders' Design, 54 U.Chi.L.Rev. 1484 (1987); Akhil Reed Amar, Of Sovereignty and Federalism, 96 Yale L.J. 1425 (1987).

140 See McConnell, 54 U.Chi.L.Rev. at 1495 (cited in note 139) (Investment in national defense requires national decisions because the costs of nuclear defense may be borne by 
greater recognition of state autonomy are largely ineffectual with respect to foreign affairs.

Three principal arguments favor a strong, independent state power. First, states can better respond to the diverse interests and preferences of their citizens. Second, states can compete against one another for citizens and economic growth through innovation in government. And third, states are often thought to be better protectors of private rights than either the larger national Congress or the President. ${ }^{141}$

With respect to national defense, the first argument assumes that states have diverse interests in national defense. The need of the states, however, is the same. The guarantee clause provides that an attack on any single state is constitutionally an attack on the nation as a whole, ${ }^{142}$ and the defense budget is set with the presumption that all states must be defended. Although citizens do have different preferences as to the level of defense spending, and the allocation of defense dollars to nuclear missiles, the individuals who express the citizens' preferences are Congressional representatives, Senators, and the President.

The second argument underlying greater state power, that of innovation, is also difficult to apply to national defense policy. State decisions that maximize the safety of citizens of one state, such as a ban on the manufacture or transportation of nuclear missiles through the state, have an adverse effect on the safety of the other forty-nine states. For example, if the citizens of Pennsylvania force nuclear missiles out of their state, the citizens of Connecticut and North Carolina could pay the price. ${ }^{143}$ States have an incentive to pass laws in which the benefits within the state exceed the costs borne by the state even if the national costs exceed the national benefits. While there is an imperfect incentive for State A to defend the safety of State B, the national character of the federal government provides it with the necessary incentive to pass laws in which the national benefits do exceed the national costs. This is not to suggest that there is no place for state innovation. Should Pennsylvania citizens devise a scheme to eliminate the need for a

State C, but benefit the citizens of States C, D, E, F.).

${ }^{141}$ Id. at 1493-1507.

142 U.S.Const. art. IV, \$ 4.

${ }^{143}$ McConnell, 54 U.Chi.L.Rev. at 1495 (cited in note 139). The Framers recognized that a state's incentive to consider the interests of outsiders was imperfect. See John Hart Ely, Democracy and Distrust 83 (1980) (privileges and immunities clause of Article IV guarantees that a state's entitlements extend to visitors because nonresidents are "a paradigmatically powerless class politically"). 
nuclear defense policy, their national representatives have a receptive national forum to deliberate on that proposal.

Third, national defense considerations are antecedent conditions for states to act as protectors of private rights. National autonomy may even justify the intrusion on certain private rights, since it is the only way to assure the exercise of all other political and individual rights. Tarble's Case illustrates this principle. State power to free the unlawfully detained was subordinate to the greater concerns raised by the Civil War.

3. The role of Congress in reviewing state actions. One might argue that the recognition of state rights need not necessarily jeopardize foreign relations or national defense. If state action infringes on the exercise of federal powers or the execution of a federal policy, Congress could legislate to override obstructive state regulation or could expressly preempt state action by statute. Yet even if Congressional action were the only source of restrictions upon the power of states to legislate in a manner affecting foreign affairs, the federal courts would retain a crucial role. In order to effectuate federal policy, the courts must pass on whether or not Congress has preempted state action. And, under standard preemption doctrine, when Congress has passed neither an express authorization of, nor an express prohibition upon, state action, the courts must determine whether Congress nonetheless intended to implement a policy in conflict with the challenged regulation, or to occupy the field of foreign relations. As has already been discussed, this last inquiry may parallel an essentially constitutional analysis.

The possibility that constitutional issues may be an important supplement to statutory preemption analysis diminishes the strength of the argument in favor of making Congress, rather than the judiciary, the arbiter of state-federal relations in the field of foreign affairs. More importantly, however, judicial review of constitutional challenges to state encroachments upon federal power over foreign affairs is functionally justifiable. First, under the pressure of the usual business of Congress, evaluation of state intrusions on foreign affairs policy may not receive high priority. ${ }^{144}$ Many of the matters that command the attention of Congress are positive measures that set the policy and programs of the country. Evaluating state actions places Congress in the position of reacting

14 See Henkin, Foreign Affairs and the Constitution 233-34 (cited in note 129) ("ordinarily the State's judgment would not be reviewed unless some aggrieved private interest challenged the agreement in court"). See also Moore, 1965 Duke L.J. at 320 (cited in note 66) (Most of the state encroachments on foreign relations "have simply been ignored"). 
defensively to the goals set by another political body. Second, Congress does not have a mechanism for learning about state and local rules that intrude upon either regulated or unregulated matters of federal interest. ${ }^{145}$ Lobbyists are able to present their grievances to Congress, but if a party seeks immediate redress, such as an injunction against enforcement of the local measure, only courts provide timely relief. Third, Congress is not suited to the task of determining whether local ordinances are incompatible, on an "ad hoc basis," with the federal system. If Congress wished to respond only to NFZs that actually impair foreign policy (thus permitting certain NFZs that do not impair foreign relations), Congress would have to study the effects and legislative history of each local rule, a task better handled in an adjudicative fashion. ${ }^{148}$ Fourth, if Congress does not act, and the courts are precluded from reviewing local enactments, "the effective final decision weighing state and federal interests would ... rest with . . . state and local lawmaking bodies"147 likely to emphasize local concerns and discount the federal interest in an unobstructed foreign policy. Judicial invalidation of state actions that encroach on national powers of defense and foreign affairs rests on the proposition that it is better for one national forum to restrict state programs that affect national defense and foreign affairs than it is for numerous state policies to experiment with a variety of programs which affect their own citizens but which also affect the national defense policy.

Judicial review of state encroachment on federal power does not deny Congress the power to amend the court's decision through statute. ${ }^{148}$ But if Congress is overcome by legislative inertia, the advantage of judicial review is that a federal body, subject to national checks, will have passed on the state statute. ${ }^{149}$

145 Jesse H. Choper, Judicial Review and the National Political Process 208 (1980).

${ }^{146}$ Id. Congress could avoid some of these problems through general legislation prohibiting the types of NFZs that it found objectionable. The courts would then have to determine whether a challenged NFZ violated the federal rule.

147 Id.

${ }^{148}$ Id. at 207. While Congressional override of a judicial decision based on constitutional principles appears peculiar, the Constitution itself envisions that Congress can overrule a constitutional bar to state action. For example, Article I, $\S 10$ bars the states from engaging in war, but the same constitutional provision permits the states to do so with the consent of Congress.

140 But see Julian N. Eule, Laying the Dormant Commerce Clause to Rest, 91 Yale L.J. 425,430 (1982), who argues that Congress can respond to state protectionism in the national market by superceding enactment. Eule avers that the Framers intended that Congress, not the courts, protect the national market. For a similar view, see Martin H. Redish and Shane V. Nugent, The Dormant Commerce Clause and the Constitutional Balance of Federalism, 1987 Duke L.J. 569 (concluding that the Constitution requires that Congress, not the courts, 
Without a doubt, Congress is a more representative body than the courts to pass on state actions that encroach on national foreign policy. But representative government is not attained if Congress fails to act, not out of a positive assessment of the impact of state legislation on national foreign policy, but due to a failure to deliberate at all. If the courts sit uneasily as arbiters of federalism challenges to local NFZs, they do so because the political branches have evaded their responsibility to define better the role of the states in the regulation of nuclear weapons. ${ }^{180}$

\section{The Dormant Commerce Clause as a Source of an Analytic Framework.}

If constitutional interpretation is an adjunct to statutory interpretation, how do we assess the legality of local measures that do not come under an express prohibition, or do not obviously undermine the purpose of a particular statute? At a general level, the inquiry will involve a balancing of local police power interests against the extent of the statute's impact on foreign affairs. It is possible to refine this balancing test, however, by using factors like those involved in the commerce clause. Recourse to the commerce clause is reasonable not because the doctrine developed there is directly applicable to the foreign affairs clauses-it clearly is not-but because it is a well-developed body of law that devises background rules restricting state regulation in an area where there is an affirmative grant of power to the national government. ${ }^{151}$ Over 100 years of judicial thinking has considered

exercise the power to regulate interstate commerce because Congress is more responsive to state concerns than the judiciary).

150 For a discussion of the role of the Court in assessing state actions that impede the interstate market, see Mark Tushnet, Rethinking the Dormant Commerce Clause, 1979 Wisc.L.Rev. 125, 164-5 ("Indeed, a political theory may be the only one upon which dormant commerce clause doctrine can rest, for the institutional problems of federal-state relations, and the separation-of-powers issues associated with them, do not easily lend themselves to solution by attention to individual rights, the major competitor of the political theory, as a general justification of judicial review").

${ }_{182}$ The relation between the federal commerce power and the federal power over defense and foreign relations has not been overlooked in the legal literature. See Moore, 1965 Duke L.J. at 299 (cited in note 66) ("The Constitution as a whole contemplates that the foreign relations power is to be exclusively federal, and state action which interferes with necessary federal responsibility or uniformity in this area must yield. The preemption doctrine which is utilized in the interstate commerce cases, although reflecting a slightly different rationale from that of a controlling federal common law or a constitutionally exclusive federal responsibility, is in essence a means of achieving federal control over state exercise of the police power in areas thought to require federal uniformity and responsibility ... . [A]s such, it lends some credence to a parallel solution in the at least equally sensitive 
thoughtfully the relevant factors that affect the constitutional invalidation of state regulations when Congress has not expressly denied states the power to act. Some of these factors are relevant to a discussion of constitutionally implied restrictions on state power to regulate national defense and foreign affairs.

The commerce clause is a positive grant of authority to Congress to regulate interstate commerce. The Supreme Court has held that there are also negative implications from the commerce clause, known as the "dormant commerce clause," which require the courts to block the power of states to regulate or tax in a manner that materially burdens interstate commerce. ${ }^{162}$ Although the Court's interpretation of the reach of the commerce clause has been historically inconsistent, ${ }^{153}$ vacillating between the belief that the commerce power is an exclusive federal power ${ }^{154}$ and the belief that the states may regulate commerce unless Congress has foreclosed state action, ${ }^{155}$ the Court resolved this tension in Southern Pacific Co. $v$. Arizona ${ }^{156}$ by balancing the state's interest in a challenged law against the federal interest in removing burdens to interstate commerce. The Supreme Court's modern jurisprudence continues to balance federal and state interests:

Where the statute regulates evenhandedly to effectuate the legitimate local public interest, and its effects on interstate commerce are only incidental, it will be upheld unless the burden imposed on such commerce is clearly excessive in relation to the putative local benefits. ${ }^{157}$

The considerations that structure this commerce clause test may be adapted to guide inquiries into the legality of Nuclear Free Zones. The present debate over NFZs has arisen because Congress has not expressly denied or permitted states the power to regulate, impede, or classify upon the basis of nuclear weapons technology. In the absence of such an express authorization or restriction,

foreign relations area.").

${ }^{152}$ For a critique of the historical development of the dormant Commerce Clause, see Eule, 92 Yale L.J. 425 (cited in note 149); Redish and Nugent, 1987 Duke L.J. 569 (cited in note 149); Tushnet, 1979 Wisc.L.Rev, 125 (cited in note 150).

${ }^{153}$ See David P. Currie, The Constitution in the Supreme Court: The First Hundred Years 1789-1888 168-83 (1985); Geoffrey R. Stone, Louis M. Seidman, Cass R. Sunstein, and Mark V. Tushnet, Constitutional Law 249-58 (1986); Tushnet, 1979 Wisc.L.Rev. at 151 (cited in note 150).

154 Gibbons v. Ogden, 22 U.S. 1 (1824); Cooley v. Board of Wardens, 53 U.S. 299 (1851).

${ }^{155}$ The License Cases, 46 U.S. 590, 676 (1874) (Taney concurring).

156325 U.S. 761 (1945).

${ }^{157}$ Pike v. Bruce Church, Inc., 397 U.S. 137, 142 (1970). 
courts must evaluate whether implied statutory or constitutional restrictions on state power bar the challenged regulation. First, the court must determine whether, despite the absence of an express restriction on state action, federal law preempts the challenged regulation because the regulation conflicts with a federal policy. If the regulation survives this first level of scrutiny, the court must then determine whether the regulation is inconsistent with the constitutional allocation of powers. As already discussed, this constitutional inquiry may be viewed either as a guide to the "occupy the field" phase of statutory preemption analysis, or as an assessment of independent, non-statutory restrictions. In light of the functional arguments in favor of judicial review presented in the preceding subsection, this comment will take the view that the constitutional considerations are relevant as a source of independent restrictions on state action. On either view, however, the "dormant foreign affairs clauses" analysis should parallel the modern commerce clause test in two respects. First, courts should ask whether the local regulation is "evenhanded" in the sense that it does not involve direct discrimination against those who participate in and support national defense policies. Second, if the regulation is nondiscriminatory, the courts should balance state and national interests by asking whether the state's interest in the safety of the locality may outweigh relevant national interests in defense and foreign affairs.

The test for the legality of NFZs thus requires, in the absence of express Congressional prohibition or approval, judicial examination of three issues: implicit conflict with federal policy, discriminatory effect, and the balance of state against federal interests. Any of the three parts of this test may justify a court's decision to invalidate an NFZ. The paragraphs that follow flesh out the detail of each of these inquiries.

The first question is one of statutory preemption. Although a local government may wish to respond to a health risk, Congress may have implicitly or expressly foreclosed local governments from passing police laws. While nuclear missiles pose some threat to citizens in close proximity, Congress has considered the risk that missiles pose to local citizens but has nonetheless opted to impose such a risk. In order for local citizens to respond to health risks presented by U.S. defense programs, those health risks necessarily must be risks which Congress either did not consider or did not even implicitly bar the states from addressing. In the case of the deployment of nuclear missiles, Congress has already evaluated the risks that a city or locality may become the target of a nuclear 
attack. In contrast, the risks associated with the manufacture of chemical warfare agents in a densely populated city may have been disregarded by Congress, which perhaps awarded the contract on the basis of the "lowest bid."

If the state action is not in conflict with a federal policy, the courts must turn their attention to constitutional factors. In theory, it would be possible to make an independent inquiry into the existence of "occupation of the field" preemption, but, as already noted, courts may sensibly have recourse to the constitutional allocation of powers in order to determine whether the complex web of statutes governing foreign and military affairs occupies a relevant field. In the absence of direct evidence of Congressional intent to occupy the field-evidence not turned up by our inquiry into the legislative history of the relevant statutes, and evidence that is likely to be rare in any event-the constitutional and "occupation of the field" inquiries will at least be very similar.

The commerce clause analysis described above suggests the character of the constitutional framework appropriate here. The first element of that commerce clause inquiry is an anti-discrimination principle: the courts must determine whether the state regulation discriminates against those outside the states to the benefit of those inside the state. State laws which discriminate against interstate commerce are per se invalid under the commerce clause. ${ }^{158}$ This principle is based on the belief that a state has an imperfect incentive to consider the interests of those unrepresented in its state legislatures. The concern over externalities has application with respect to the foreign affairs powers as well, for the adoption of an NFZ barring the deployment of nuclear missiles in State A imposes the costs of nuclear terrorism and attack on other localities. But NFZ advocates respond to this argument by claiming that the thrust of the NFZ movement is to rid the entire nation of nuclear weapons. Concerns that one state may attempt to saddle another with the costs of a national defense policy are better addressed in connection with the need for a uniform national policy and the existence of strong national interests, both discussed

\footnotetext{
${ }^{158}$ See Philadelphia v. New Jersey, 437 U.S. 617 (1978) (invalidating New Jersey law discriminating against the dumping of out-of-state garbage at a New Jersey waste site). The anti-discrimination principle has application outside the commerce clause as well: the states may not discriminate against the federal government or those with whom it conducts business. See Nash v. Florida Industrial Commission, 389 U.S. 235, 239 (1967) ("Florida should not be permitted to defeat or handicap a valid national objective by threatening to withdraw state benefits from persons simply because they cooperate with the Government's constitutional plan").
} 
below.

Instead of acting as a bar to state protectionism, the anti-discrimination principle, when applied to the foreign affairs and national defense powers, invalidates local laws which penalize defense contractors. Such laws discriminate against corporations doing business relations with the federal government in furtherance of a national nuclear defense policy. Viewed in this manner, the antidiscrimination principle is a consequence of the more general rule that a desire to obstruct federal policy is an illegitimate basis for local action.

When a state regulation is not preempted by federal statute, and does not discriminate against federal defense policy, then the courts should balance the federal interest in an unobstructed defense program against the state's interest in the disputed regulation. Again, factors used in commerce clause analysis may help to structure this balancing.

First, courts must determine whether the state regulation is local or national in character. ${ }^{159}$ In commerce clause cases, the inquiry often amounts to a determination of whether the state regulation seeks to control policies better served by a uniform national rule. The courts have been more inclined to believe that a regulation responds to genuine local safety concerns, rather than rejects a uniform national market, when different treatment from state to state is appropriate. ${ }^{160}$ In the context of the foreign affairs powers, courts should inquire whether a state regulation responds to a local concern which is not itself a component of the national defense policy.

A second factor is whether there are less burdensome alternatives than that proposed by the state which can meet local concerns with minimal compromise of national objectives. ${ }^{161}$

In commerce clause cases, a third factor is whether the state action may be characterized as market participation. This factor, often recognized as an exception to the dormant commerce clause,

${ }^{159}$ Cooley, 53 U.S. at 319 ("[The] power to regulate commerce, embraces a vast field, containing not only many, but exceedingly various subjects, quite unlike in their nature; some imperatively demanding a single uniform rule, operating equally on the commerce of the United States in every port; and some . . . imperatively demanding that diversity, which alone can meet the local necessities of navigation."); S.C.Hwy.Dept. v. Barnwell Bros., 303 U.S. 177 (1938).

${ }^{160}$ Barnwell Bros., 303 U.S. at 185.

${ }^{161}$ See Dean Milk Co. v. Madison, 340 U.S. 349 (1951) (invalidating Madison regulation restricting sale of milk not bottled within five miles of the city because reasonable, nondiscriminatory alternatives could have protected the local interest in unadulterated milk). 
grants local governments substantial leeway in structuring their economic relations as purchasers and sellers. ${ }^{162}$ The doctrine is anomalous even in commerce clause jurisprudence, for if applied to its full extent, it would elevate state sovereignty over the value, articulated in Cooley v. Board of Wardens, of an unencumbered national market. ${ }^{183}$ The market participant doctrine seems even less applicable to the foreign affairs powers than the other factors used in dormant commerce clause jurisprudence. In contrast to the commerce powers, which the states share, the concurrent role of the states in the field of foreign affairs is minimal. If one believes, however, that states and localities ought to have greater power when acting in their proprietary capacity, then the market participant doctrine might provide an analytic framework for introducing that principle into "dormant foreign affairs clauses" jurisprudence.

\section{Constitutionally Required Balancing: The Application of IMPLIED RESTRICTIONS}

This section applies the analysis developed above to the four test cases described in the introduction. The combination of statutory and constitutional restraints on local action affecting foreign affairs will be shown to require the invalidation of most of the state and local restrictions on nuclear weapons production. ${ }^{164}$

${ }^{182}$ See White v. Mass. Council of Constr. Employers, 460 U.S. 204 (1983) (upholding city order requiring all construction projects funded by city be performed by a work force consisting of half residents of the city); Reeves, Inc. v. Stake, 447 U.S. 429 (1980) (upholding state regulation to supply in-state customers with cement orders before meeting the orders of out-of-state customers); Hughes v. Alexandria Scrap Corp., 426 U.S. 794 (1976) (upholding state offer to pay scrap processors who dispose of the state's abandoned automobiles).

${ }^{163}$ The Court has said that, in principle, a state's participation in the market is distinct from regulatory measures that impede private trade in the free market. Reeves, 447 U.S. at 436-37. While the Court has upheld state actions that focus economic benefits of state spending on the state or local economy, see note 162, it has invalidated state actions which appear to pursue policy goals outside the state. See South-Central Timber Dev., Inc. v. Wunnicke, 467 U.S. 82, 97 (1984) (plurality opinion) (state "may not impose conditions, whether by statute, regulation, or contract, that have a substantial regulatory effect outside of that particular market"). Generally, however, the Court has not formulated succinct guidelines as to when a local government's market participation constitutes market regulation.

${ }_{164}$ The argument here rejects the analysis of Weaver, et al., 17 Loyola U.L.J. at 574-75 (cited in note 93). That article states that the grant of foreign policy powers to the national government does not preclude state and local authorities from regulating private parties, such as nuclear weapons contractors, unless Congress has explicitly formulated a contrary policy. Yet Zschernig $v$. Miller and Hines $v$. Davidowitz both involved state regulation of private parties. When the regulation of private parties affects national defense or foreign affairs, the regulation may be invalidated as an unconstitutional encroachment upon federal powers. Moreover, the Chicago NFZ analyzed in the Weaver article, while ostensibly di- 
1. Test case one. The first test case is a statute which bans from the locality navy ships which carry nuclear weapons (a "home port" statute) or bans the placement of land-based missiles near a community. Such a statute is similar to that which the New York state courts found unconstitutional in Fossella $v$. Dinkins. The only difference between the test case and Fossella is that, in the test case, the state also seeks to ban the deployment of land-based missiles from the locality.

Here, the statutory preemption analysis cuts strongly against the legality of the local regulation. The determination of missile deployment sites and naval harbors most likely involved an assessment of the comparative merits of various locations, and so preempts state opposition. Moreover, the statutes discussed in Section II.A also justify holding the local regulation preempted. The Arms Control and Disarmament Act, which provides that nuclear disarmament must be centrally coordinated under the exclusive control of the federal government, may preempt a state action that seeks to promote disarmament by interfering with considered national nuclear policy. Finally, the Atomic Energy Act of 1954 requires that state regulation of atomic energy be for some purpose other than nuclear safety. Although the Act has been construed to permit local regulations framed to achieve economic rather than safety objectives, the language and history of the Act-discussed in Section II.A.1-do not warrant extending this permissive construction to military applications. In test case one, safety from nuclear hazards appears to be at the core of the local policy.

Even if test case one were to survive the "direct conflict" preemption inquiry, the constitutional factors (which might also be used to guide a statutory "occupation of the field" analysis) would also provide good grounds for invalidating the local regulation. The regulation directly and exclusively targets agents of national defense policy. Moreover, a balancing of state and national interests suggests that the national interest is stronger in this case. Only the presence of a localized interest or threat cuts in favor of upholding the statute: the locality may, indeed, be subject to attack and terrorism. But the externalities associated with a community barring the deployment of nuclear weapons in a locality create the need for one national policy. Only the national government has the incen-

rected toward private parties, is premised on a rejection of the federal nuclear defense policy. See Chicago Municipal Code ch. 202, cl. 8 (1986) ("WHEREAS, The public morality is affronted by the presence of an industry profiting from activities which may ultimately lead to unprecedented death and destruction in this community ...."). 
tive to properly weigh the risks to the local community and the nation against the value of employing nuclear weapons. On the other hand, if one believes that the principles behind the market participant doctrine ought to be imported into the analysis of the foreign affairs powers, they may have some purchase here. If a city or state owns the harbors or lands in question, it might be said to have a special proprietary power allowing it to deny access to those areas. Yet even if recognized, such a power is not of comparable importance to the need for a nationally formulated policy with respect to weapons deployment.

The above analysis indicates that the outcome in Fossella $v$. Dinkins is correct, but for the wrong reason. The Fossella courts interpreted the defense powers as exclusive to the federal government such that state actions that infringe upon national defense are invalid even when Congress has not acted. Although there are dormant powers which attach to the defense and foreign affairs clauses, the court incorrectly asserted that there are no local concerns which justify infringement upon a national defense program. The decision goes too far. The local concerns in Fossella were outweighed by the need for a single national policy. Under a dormant defense analysis there may be local concerns which outweigh concerns for a single national policy, particularly if the local program only incidentally affects the national defense policy. The Fossella courts incorrectly held there were no local concerns at issue. If applied to other cases, the Fossella analysis could create an untenable situation in which Congress might overlook the safety concerns of a locality, and localities would be powerless to address the particularized problem on their own.

2. Test case two. The second test case is a statute which bans the manufacture of nuclear weapons or nuclear weapons components in the locality.

Again, the first inquiry is whether a local ban on the manufacture of nuclear weapons is expressly or implicitly preempted by federal law. The express language of defense contracts probably does not require that nuclear defense contractors manufacture nuclear components in particular cities and localities. However, the intent of local measures to limit nuclear weapon production in their communities may clash directly with the federal disarmament plans. If a local community seeks to prevent the manufacture of nuclear weapons anywhere, then the measure should be viewed as preempted by the Arms Control and Disarmament Act. It would be possible, however, for a local community to premise its ban on the manufacture of nuclear weapons and nuclear weapons compo- 
nents on safety concerns associated with the handling of fissionable materials. But in this case, the Atomic Energy Act would preempt state action. In order to avoid preemption under the Atomic Energy Act, the state ban must be premised on conditions other than radiation safety, perhaps the costs of fire and safety plans for example. Yet even if the state law were framed in economic terms, the legitimate role of state regulation may not extend beyond commercial ventures to nuclear weapons contractors.

If the local action survives preemption analysis, the courts should then subject the statute to scrutiny under the anti-discrimination principle. On its face, the ban on the production of nuclear weapons components discriminates against defense contractors. Discrimination may become more apparent if the local government ignores the more immediate safety threats of other industries, such as the manufacture of toxic substances, the burning of pollutants, or the transportation within the locality of carcinogenic substances.

However, if the courts find that NFZs like test case two do not discriminate against a federal defense policy, the courts should then balance the state and federal interests in the challenged regulation. As in test case one, the only factor which favors upholding the local regulation is the state's interest in local safety. The presence of nuclear weapons manufacturers in a locality could threaten local citizens who may become targets of nuclear terrorism or a preemptive attack. But in contrast to the state's interest in test case one, the state's interest in test case two is more attenuated. Some nuclear weapons contractors, as broadly defined, do not represent a safety risk for local residents. Nuclear weapons contractors include many industries, such as those which manufacture electronic guidance systems, computers, and electrical wiring. These industries include such general civilian manufacturers as AT\&T, Texas Instruments, ITT, General Electric, Litton Industries, Westinghouse Electric, General Motors, IBM, and Rolls Royce. ${ }^{165}$ In this respect, a state's interest in preventing nuclear terrorism or attack may not be served by measures like that in test case two.

The remaining factors support the invalidation of the statute. First, as with test case one, states have an imperfect incentive to consider national defense needs when they pass local health laws. While a local community may face nuclear attack due to the pres-

${ }^{185}$ See Nuclear Free America, List of Top 50 Nuclear Weapons Contractors (March 1988)(on file with the University of Chicago Law Review). 
ence of certain manufacturing operations, the decision to ban those operations has a greater cost nationally than it does locally. A local community may bear some costs from its action, namely the loss of jobs and economic growth that the industry brings to a community, but the greatest cost still may be borne by other states. NFZs have the potential to affect substantially national defense programs. The award of federal contracts is premised upon the notion that the contractor has facilities capable of completing the project. A single NFZ may have little effect on the ability of a contractor to meet the federal demand. But as the number of NFZs increase-and their number now exceeds 130 -contractors may be placed in a position of building a new plant, removed from an available labor pool, or changing to a locality which has not banned the production of nuclear weapons components. The contractor's ability to complete a federal defense contract is thus inversely proportional to the number of NFZs across the country.

There are also alternative state measures that might meet a local government's concerns other than a wholesale ban on the local manufacture of nuclear weapons components. Test case two is not narrowly tailored to address the risk of nuclear terrorism or attack. The regulation does not distinguish among contractors that handle nuclear materials, those that do not, and those not producing nuclear weapons components in the locality. An alternative statute could be more closely tailored to the risk which different industries pose to the city or locality.

3. Test case three. The third test case is a statute which bars a local government from contracting with a nuclear weapons manufacturer..$^{188}$

Preemption turns on what local regulators intended when they passed the ordinance. If their intent is to steer nuclear weapons manufacturers away from their weapons production and into other socially productive enterprises, ${ }^{167}$ then the intent conflicts with the

166 Investment and contract bans should be distinguished. If one accepts the faith of free market economists in the essential fungibility of investment dollars, bans on investment do not directly obstruct a federal program. Other investors will take the place of the boycotting local government. Contracts, however, are not fungible and should be subject to a more restrictive analysis. Even if investment dollars are less fungible than is frequently asserted, a local government divestment plan, or even many of them, is likely to cause only a minor increase in government contractors' cost of capital. For some recent evidence on fungibility, see Andrei Shleifer, Do Demand Curves for Stocks Slope Down?, 41 J.Fin. 579 (1986).

${ }_{167}$ The rationale for the restriction, according to the preambles of some of the NFZ laws, is to "encourage those corporations to abandon their work on nuclear weapons in favor of work that contributes to the public welfare." See Marin County Nuclear Free Zone Ordi- 
goals of the Arms Control and Disarmament Act, which aims to give Congress and the President sole responsibility for the national nuclear weapons disarmament strategy. If the local measure is not directed toward nuclear disarmament, the measure need not necessarily conflict with Congressional statutes.

However, the constitutional factors strongly favor invalidation of the ordinance. The anti-discrimination principle provides one strong reason for striking down the statute: restrictions on public contracts with nuclear weapons industries penalize a class of persons on the basis of association with the advancement of a federal policy. Moreover, test case three does not involve a strong local interest. First, unlike test cases one and two which respond to the risks that nuclear missile production facilities or deployed missiles present to the surrounding communities, a ban on contracting with nuclear weapons industries does not respond to any local concern. The contracting restriction applies when production is occurring in some locality other than the locality imposing the contracting ban. The residents of municipal governments that contract with the nuclear weapons industry are not subject to nuclear terrorism or attack because they have commercial relations with companies that produce nuclear weapons or weapons components in some state in the country.

Second, the intensity of sporadic local dislike for a national defense policy, which is itself not strong enough to elect new national representatives, creates a climate in which a uniform national policy is required. There may be a minority of local governments, which nonetheless are substantial in number, that can exert very real pressure on certain industries not to contract with the federal government. The externalities associated with local expressions of opposition to defense programs justify a national policy.

Third, there are less restrictive alternatives to express public opposition to the nuclear arms build-up than a ban on public contracting with the nuclear weapons industry. Local governments can pass non-binding measures against the manufacture and use of nuclear weapons. In this way, local governments retain their ability to speak as a city or a state and yet do not impair national defense policy. ${ }^{168}$ The usual channels of public lobbying are still available

nance, No. 2924, preamble, cl. 8 (1986) (cited in note 11).

${ }^{168}$ See Letter from Massachusetts Assistant Attorney General to Tisbury Town Clerk (July 19, 1983)("A resolution or a nonbinding public opinion advisory question would be a more proper method for the voters to express their feelings on nuclear weapons" than a bylaw that prohibits the manufacture or transfer of nuclear armaments or associated products 
to local governments. Moreover, municipalities, counties and states that oppose the federal nuclear weapons policies can elect representatives who will vigorously champion their constituents' preferences.

The market participant doctrine, if generalized and imported into analysis of the foreign affairs clauses, may offer some support for the statute in this test case. But again, even if one accepts the legitimacy of such an extention of the market participant doctrine, the principles underlying the doctrine are of little weight in comparison to the national defense interests described above.

4. Test case four. The last test case is a general safety statute which subjects all manufacturers of toxic or nuclear materials within the municipality, including those who are defense contractors, to restrictive health and safety regulations. This case resembles the Cambridge restriction at issue in Arthur D. Little, Inc. This measure most resembles the kind of local health statute that serves state interests but does not frustrate federal policy.

The first inquiry is whether national law preempts local safety regulations that apply to all manufacturers of hazardous substances. The Atomic Energy Act provides that states cannot regulate the safety aspects concerning atomic energy. Nuclear radiation hazards are subject to federal regulation only. But the Atomic Energy Act does not bar states from regulating the hazards associated with non-nuclear and other hazardous materials. Although the Act is permissive with respect to state regulation of nuclear power plants, it might not permit a state to regulate nuclear weapons contractors on what are essentially safety-related grounds that have been recast in economic terms.

On the other hand, Congress or the executive probably awarded the chemical warfare agents contract on the "lowest bid" approach, without ever considering the ramifications of a toxic chemical leak on a densely populated city. If so, the award of the contract would have no preemptive effect.

If the state action survives preemption analysis, a court then assesses whether the measure discriminates against defense contractors. The anti-discrimination principle does not require that courts invalidate a general health regulation. A safety regulation, such as the Cambridge health restriction, applies to the manufacture of all toxic substances.

If the local measure survives scrutiny under the anti-discrimi- 
nation analysis, then the courts would balance the federal and local interests in the challenged regulation. First, the health regulation responds to a particular, localized interest. For example, in Arthur D. Little, Inc., in the wake of the Bhopal chemical release, the city of Cambridge responded to the manufacture of five, highly toxic chemicals within the city itself. Second, the externalities associated with health restrictions on selected plants may not warrant a national policy. However, if Congress considered the possible safety hazards associated with chemical warfare production and intended to bar local regulation of those hazards, local regulation of the dangers associated with defense manufacturing is preempted by national legislation.

Third, there are no less restrictive alternatives for the control of localized safety risks than a narrowly tailored health and safety statute. Should Congress believe that even a narrowly tailored health regulation impairs national defense interests, Congress may statutorily overrule the regulation.

The test adopted by the Arthur D. Little, Inc. court is a correct analysis of the scope of implied restrictions on the states to regulate foreign relations and national defense policy. The Supreme Judicial Court of Massachusetts appropriately considered the federal interests in play and balanced them against specific local concerns over the dangers of chemical production.

\section{CONCLUSION}

This comment has discussed two possible interpretations, both reflected in Supreme Court doctrine, of the legal restrictions upon state and local regulation affecting the national defense and foreign affairs. The first interpretation is that the enumeration of federal powers precludes all state action in areas which affect federal powers. The second interpretation focuses almost entirely on issues of statutory preemption. The test proposed in this comment accommodates both the preclusion and preemption line of cases by setting out federal statutory limits on Nuclear Free Zone regulations, suggesting a link between occupation of the field preemption and constitutional interpretation, and drawing upon commerce clause jurisprudence to structure both constitutional and "occupation of the field" analysis. Under the resulting "dormant defense and foreign affairs analysis," many of the recent Nuclear Free Zone ordinances are invalid as unconstitutional intrusions on the federal power to provide for national defense and to conduct foreign affairs. However, the analysis does uphold some local enactments that respond to peculiarly local health risks. 